\title{
Review \\ Why are women predisposed to autoimmune rheumatic diseases?
}

\author{
Jacqueline E Oliver ${ }^{1}$ and Alan J Silman ${ }^{2}$
}

1 University of Manchester, Oxford Road, Manchester, M13 9PL, UK

2Arthritis Research Campaign, Copeman House, St Mary's Court, St Mary's Gate, Chesterfield S41 7TD, UK

Corresponding author: Alan J Silman, a.silman@arc.org.uk

Published: 26 October 2009

This article is online at http://arthritis-research.com/content/11/5/252

(C) 2009 BioMed Central Ltd
Arthritis Research \& Therapy 2009, 11:252 (doi:10.1186/ar2825)

common in women than in men, with a peak age of onset in the fifth decade of life. In later years, the incidence-gender ratio reduces to around $2: 1$ in 55 to 64 year olds, shifting to a male excess in those over 75 years old [3]. The gender ratio for Scl has been reported to vary between 1:1 and 14:1 [4]. The ratio varies between age groups with slightly higher ratios (3.4:1) in the childbearing years (aged 15 to 44 years) and lower ratios $(2.4: 1)$ in the postmenopausal years, with the female:male ratio averaging 3:1 [5]. SLE has an earlier disease onset than both RA and Scl, peaking in the childbearing years (late teens to early forties) with a female:male ratio of around 9:1 [6].

\section{Geographic location and ethnicity}

Autoimmune diseases are known to vary by both ethnicity and geographical location. RA shows a wide variation in its incidence and prevalence worldwide. Southern European countries have a lower occurrence compared with north European and North American countries, and the disease also has a lower prevalence in developing countries [7]. In all studies, the female RA rate is two to three times higher than that in males [8]. SLE also varies geographically, with a higher prevalence in the USA compared with Scandinavian countries and the UK [9]. Some studies have found a higher female:male ratio - about 14-fold higher in an English study compared with a fourfold difference in Sweden - but these differences are more likely to be due to the smaller number of cases in males, rather than to true geographical differences in gender ratios [10]. There are also geographical variations in the occurrence of Scl. The prevalence is higher in the USA and Australia compared with Japan and Europe [4]. There is some evidence of a north-south divide in Europe, with France and Greece having a higher number of cases than Iceland and England. There is a consistent female excess in all populations varying from $3: 1$ to $14: 1$ [11].

$\mathrm{Cl}=$ confidence interval; $\mathrm{IL}=$ interleukin; OCP = oral contraceptive pill; OR = odds ratio; RA = rheumatoid arthritis; Scl = scleroderma (systemic sclerosis); SLE = systemic lupus erythematosus; TNF = tumour necrosis factor. 
Table 1

\begin{tabular}{lcll} 
Sex ratios for connective tissue autoimmune diseases & & & \\
\hline Disease & Female:male ratio & Peak age at onset & Reference \\
\hline Rheumatoid arthritis & $2: 1$ to $3: 1$ & Forties & [83] \\
Systemic lupus erythematosus & $9: 1$ & Late teens to early forties & {$[6]$} \\
Systemic sclerosis & $3: 1$ & Forties & \\
\hline
\end{tabular}

aKnown to vary due to ethnicity.

African-Americans and African-Caribbeans both have an increased incidence of SLE compared with Caucasians, and race is associated with disease presentation [9]. Whilst the incidence is higher in Africans than Caucasians, when comparing males and females the gender ratio remains about 9:1 [10]. Racial variations in the epidemiology of Scl show that the disease is higher and more severe in African American women and there is a younger age at onset [12].

While this epidemiological evidence can give us some insights into which populations are more susceptible to autoimmune diseases, it does not explain the excess of these diseases in women. We therefore must examine other hypotheses to explain the excess. The major focus of a number of studies has been a hormonal basis for the disease, due to the hormonal fluctuations to which women are exposed throughout life.

\section{Influence of sex hormones Biological basis}

The higher incidence of autoimmune connective tissue disorders in women has led to much interest into whether or not there is a hormonal influence on disease risk. Females have enhanced immunoreactivity, compared with males, with higher immunoglobulin levels and enhanced antibody production to antigen stimulation [13]. The immune response in women is more T-helper type 2 predominant compared with men, who have a T-helper type 1 response [1].

The sex hormones oestrogen, androgen and prolactin have all been proposed as having a role in susceptibility to autoimmune diseases. These hormones all modulate the immune response via androgen and oestrogen receptors. The role of sex hormones is not simple, however, and a complex interaction between the hormones may influence disease susceptibility. Oestrogen, progesterone and testosterone all have the same precursor: cholesterol. Further, their common intermediate metabolites (dehydroepiandrosterone and oestradiol) also interact with the immune system. The circulating levels of sex hormones in both genders represent the relative conversion of androgens and oestrogens [14]. Levels of oestrogen and progesterone decline with increasing age, with an increased rate of decline in the perimenopausal and menopausal years, and with progesterone declining at a faster rate than oestrogen. Oestrogen and prolactin are both proinflammatory hormones [14] and the increased exposure in women may, in part, explain the high female:male ratio. How oestrogen exerts its action is discussed more fully in several review articles $[15,16]$.

There are some interesting observations, however, in relation to autoimmune diseases. Oestrogen may have a direct role in the pathogenesis of SLE: therefore, calcineurin (which enhances the inflammatory response) is induced by oestrogen in women with SLE, while in healthy women it is not [17]. This response is thought to be gender specific, suggesting that the oestrogen receptor response is altered in female SLE patients [18]. There is some evidence that the oestrogen receptor has a differential function in women with SLE whereby oestrogen enhances T-cell activation in women with SLE, resulting in amplified T-cell/B cell interactions, Bcell activation and autoantibody production [19]. Hyperprolactinemia is observed in some autoimmune diseases - most notably in SLE [20]. By contrast, androgens (such as testosterone) are anti-inflammatory hormones [14]. Such data are consistent with studies showing that men with RA have significantly lower levels of testosterone [21].

\section{Endogenous hormone levels and disease risk}

Studies on hormone levels are difficult as treatment for the disease or the disease itself can often affect hormone levels and reports on pre-disease hormone levels are not always available. Pre-disease hormone levels may give an insight into why some people develop RA and others do not, and this was examined in a nested case-control study [22]. There were no differences, however, in pre-disease testosterone and dehydroepiandrosterone sulphate levels between cases and controls in either men or women [22]. A cross-sectional study found that both free and serum testosterone levels were lower in males with RA compared with healthy controls, which supports the hypothesis that male sex hormones may protect against the development of RA [23]. Although testosterone levels were reduced, one study found that this was not related to disease activity in RA [21]. Multivariate analysis showed that men with both low serum cortisol and low testosterone levels were at an increased risk of developing RA [24,25].

Men with RA have variations in a number of sex hormones [26]. Dehydroepiandrosterone sulphate and oestrone concen- 
trations have been found to be lower in male RA patients compared with healthy controls [26], while oestradiol was higher and correlated with inflammation levels. A recent review and meta-analysis of the role of the sex hormones (dehydroepiandrosterone/dehydroepiandrosterone sulphate, progesterone, testosterone, oestradiol and prolactin) in SLE showed that female SLE patients have an altered sex hormone milieu, with increased prolactin and oestradiol levels and reduced androgen levels, and suggested that SLE development in women is more closely related to gonadal sex steroid alterations [27].

\section{Disease risk and markers of hormonal status}

Menarchal age and menopause

The longer the lifetime period of menstruation, the greater the lifetime exposure to proinflammatory sex hormones. Of interest, therefore, is the observation that an early age of menarche has been associated with doubling the risk of SLE (relative risk $=2.1,95 \%$ confidence interval $(\mathrm{Cl})=1.4$ to 3.2 ) for age $\leq 10$ years at menarche [28]. This has also been found for the risk of seropositive $\mathrm{RA}$ (relative risk $=1.6,95 \% \mathrm{Cl}=$ 1.1 to 2.4 ) [29]. Very irregular menstrual cycles, which are presumed to be a consequence of excess hormone production, were associated with an increased risk of RA (relative risk $=1.4,95 \% \mathrm{Cl}=1.0$ to 2.0 ) in data from the Nurses' Health Study [29].

Somewhat surprisingly given this scenario, the risk of SLE was also higher in postmenopausal women who had a surgical menopause (relative risk $=2.3,95 \% \mathrm{Cl}=1.2$ to 4.5 ) or an earlier age at natural menopause [28] - suggesting oestrogen deficiency may have a role, or specifically an acute change in its production. Alternatively, preclinical disease may lead to an earlier natural menopause and act as a marker for susceptibility to the disease. The results from this study provide evidence that the timing of oestrogen exposure is related to the risk of SLE [28].

\section{Pregnancy}

Pregnancy has different effects in different autoimmune diseases. RA frequently goes into remission during pregnancy $[30,31]$, and furthermore the pregnancy period itself is associated with an incidence reduced by around 70\% [32]. By contrast, pregnancy in SLE can cause the disease to flare and some patients have monthly worsening of the disease at menses. Pregnancy does not appear to cause disease deterioration in patients with Scl. RA is T-cell mediated whilst SLE is B-cell mediated, which could explain the differential effects in pregnancy.

Subfertility in women with autoimmune diseases is also an issue, with some studies suggesting a link between nulliparity and autoimmune disease [33]. What is unclear is the direction of the link. Do the pathological changes resulting from autoimmune disease, even when in a preclinical stage, decrease the risk of successful conception? For example, changes resulting from the production of autoantibodies, which decrease fertility either by suppressing ovulation or by reducing the chance of successful fertilization. Alternatively there is the possibility that unsuccessful pregnancy (pregnancies) may be a direct explanation for the increased risk of the disease - through such paths as enhanced likelihood of persistence of foetal cells in the maternal circulation. There is also the possibility of confounding, with hormonal factors being linked to both failed pregnancy and disease risk. As an example, prolactinoma is a well-recognized cause of subfertility and the high levels of prolactin seen in such women may contribute to disease development [34,35].

Similarly, the precise mechanisms behind the remission of RA during pregnancy remain unclear. One study found that IL-2 was decreased during pregnancy (especially in the third trimester) while soluble TNF receptor p55 and p75 were both increased, which would suggest a downregulation of T-helper type 1 responses [36]. There is also the increased risk of postpartum flare/disease development. One study found that the risk of RA is fivefold during the first 3 months postpartum, with the highest risk being after a first pregnancy [32]. There is a widespread variability, however, in disease response during pregnancy [37].

\section{Breastfeeding and rheumatoid arthritis}

The well-described postpartum flare of RA may be induced by breastfeeding [38]. The onset of RA has been linked to breastfeeding, with one study finding breastfeeding after a first pregnancy increases the risk five times, breastfeeding after a second pregnancy increases the risk twofold and breastfeeding presents no increased risk in subsequent pregnancies [34]. This study examined the short-term risk of breastfeeding on the onset of RA in the postpartum period when hormone levels are undergoing major fluctuations. The results could suggest that there might be a group of women in whom lactation may be a risk factor. This risk could be due to increased secretion of the proinflammatory hormone prolactin. Studies using bromocryptine, which inhibits prolactin production, have shown some improvement in disease in patients with autoimmune diseases, with more consistent improvements in SLE patients than in those with RA [39].

There have also been a number of studies on the longer term effects of breastfeeding. Thus the Nurses' Health Study examined a number a hormonal influences on RA including breastfeeding [29], and found that the risk of RA decreased as the duration of breastfeeding increased. Women with a cumulative lifetime history of breastfeeding for more than 24 months have a halving in risk, although whether this reflects a long-term but unexplained protective effect or is confounded by other protective factors is unclear [29]. A community-based prospective cohort study also found that the duration of breastfeeding was associated with a reduced risk of $\mathrm{RA}$ (odds ratio $(\mathrm{OR})=0.46,95 \% \mathrm{Cl}=0.24$ to 0.91 for women with $\geq 13$ months of breastfeeding; $O R=0.74$, 
$95 \% \mathrm{Cl}=0.45$ to 1.20 for those with 1 to 12 months of breastfeeding) [40]. These latter studies have been to determine the long-term protection that breastfeeding may offer against disease development.

\section{Breastfeeding and systemic lupus erythematosus}

Oestrogen and prolactin are thought to increase the progression of murine SLE. Studies in humans, however, have found that breastfeeding was associated with a decreased risk of SLE (OR $=0.6,95 \%=\mathrm{Cl} 0.4$ to 0.9$)$. This populationbased case-control study of 240 SLE patients found that the risk was further reduced with an increasing number of babies fed and an increasing total time of breastfeeding [41]. These results suggest little evidence for SLE being driven by oestrogen or prolactin exposure in humans.

\section{Pregnancy history and scleroderma}

A population-based study of over 2,000 Swedish women showed that nulliparity was associated with an increased risk of $\mathrm{Scl}(\mathrm{OR}=1.37,95 \% \mathrm{Cl}=1.22$ to 1.55$)$ whilst an increasing number of births was associated with a decreased risk [33]. In women who had children, a younger age at onset was associated with an increased risk of Scl. The increased risk with lower parity may be partly due to subfecundity caused by the subclinical disease or there may be a protective effect of pregnancy through an unknown mechanism.

An Italian case-control study has also shown that parous women have a reduced risk of $\mathrm{Scl}(\mathrm{OR}=0.3,95 \% \mathrm{Cl}=0.1$ to 0.8 ) and that the risk decreased with increasing number of children, from $\mathrm{OR}=0.6$ for women with one child to $\mathrm{OR}=$ 0.3 for those women having three children or more [42]. Women who had a history of abortive pregnancies were also at a decreased risk of $\mathrm{Scl}(\mathrm{OR}=0.5,95 \%=\mathrm{Cl} 0.1$ to 1.5$)$.

Differences have also been found in age of onset, in disease severity and in course and cause of death in women who develop Scl prior to pregnancy, compared with those who develop the disease after pregnancy [43]. There are few data on the role of breastfeeding and the risk of Scl, which is perhaps not surprising given the disease's later age of onset.

\section{Exogenous hormones and disease risk}

Women are also subject to further exposure to hormones when levels are artificially boosted with use of the oral contraceptive pill (OCP) and postmenopausal hormone replacement therapy. The OCP is typically a combination of oestrogen and progestin taken on a monthly basis and can be taken over long periods of time. Hormone replacement therapy is usually short term (ideally $<5$ years) and provides low doses of oestrogen sometimes combined with progesterone and testosterone.

There have been many studies on the role of OCP use in RA. The majority of studies, but not all [40], have found that current or ever use of the OCP has a protective effect against
RA development, although based on data from a large followup study it is possible that OCP use postpones RA rather than prevents it [44]. Indeed, the well-described recent decrease in incidence of RA that has been reported in several populations of women may be in part due to increased use of the OCP [45]. Several recent studies have found no significant association between the use of hormone replacement therapy and the incidence of RA [46-48].

Evidence on the role of OCP use in the incidence of SLE is mixed (Table 2). Whilst a recent large prospective study found that both use of the OCP and postmenopausal hormones significantly increased the risk of SLE [28], other studies have found no evidence for an increased risk [41]. An interesting and unusual case report is that of new-onset SLE in a transgender man taking feminizing sex hormones [49]. Phytoestrogens may also have a role in SLE; compounds such as diethylstilbestrol and bisphenol A have been shown to increase autoantibodies in a mouse model [50]. The effect of oral contraceptives on disease activity in SLE has also been the subject of a number of studies. Data from clinical trials suggest that OCP use has no effect on existing SLE. The SELENA trial - a double-blind placebo-controlled trial found no difference in the severe flare rate in patients with inactive disease or stable active disease when using OCPs [51]. Another clinical trial found no increase in flares in women randomized to use oral contraceptives, an intrauterine device or the progestin-only pill [52].

\section{Genetics and related phenomena}

Genetic factors also affect the risk of these diseases in both males and females. It is interesting to evaluate whether genetic influences vary between the sexes. A major wholegenome screen found that while the single nucleotide polymorphism marker rs11761231 (on chromosome 7) had no effect on RA in males, it had a strong and apparently additive effect in females - which may represent one of the first sex-differentiated effects in human diseases [53].

There are also some indications that sex chromosomes may play a part in contributing to disease onset or severity. The $X$ chromosome contains a number of both sex-related and immune-related genes that determine immune tolerance and sex hormone levels. Conditions that affect the $\mathrm{X}$ chromosome have been studied to see whether they can explain the female excess in autoimmune diseases. We discuss these investigations below, based on studies of $X$ chromosome inactivation, $\mathrm{X}$ monosomy and Klinefelter's syndrome in relation to the autoimmune diseases.

\section{$\mathrm{X}$ chromosome inactivation}

$X$ chromosome inactivation is an epigenetic system whereby one of the $X$ chromosomes in females gets switched off to ensure that only one copy of $X$ chromosome genes is available in early embryonic cells. This random switching off happens early in development and can either switch off the 
Table 2

Studies on the use of the OCP and postmenopausal hormones and the risk of SLE

\begin{tabular}{|c|c|c|}
\hline Type of study & Comments & Reference \\
\hline \multirow[t]{3}{*}{ Case-control } & Little or no association & [41] \\
\hline & $\begin{array}{l}\text { Little association between SLE and current use or duration of use of hormone replacement therapy } \\
\text { or OCP }\end{array}$ & \\
\hline & No association with previous use of fertility drugs & \\
\hline \multirow[t]{3}{*}{ Prospective cohort } & Slightly increased risk & [84] \\
\hline & OCP use: relative risk $=1.4(95 \% \mathrm{Cl}=0.9$ to 2.1$)$ & \\
\hline & Duration of OCP use or time since first use did not increase the risk & \\
\hline \multirow[t]{4}{*}{ Case-control } & Increased risk (current oestrogen users with exposure $>2$ years) & [85] \\
\hline & SLE: odds ratio $=2.8(95 \% \mathrm{Cl}=0.9$ to 9.0$)$ & \\
\hline & Discoid lupus: odds ratio $=2.8(95 \% \mathrm{Cl}=1.0$ to 8.3$)$ & \\
\hline & $\begin{array}{l}\text { When all cases were combined there was a difference between long-term users of oestrogen only } \\
\text { (odds ratio }=5.3,95 \% \mathrm{Cl}=1.5 \text { to } 18.6 \text { ) and those who used oestrogens combined with progestogens } \\
\text { (odds ratio }=2.0,95 \% \mathrm{Cl}=0.8 \text { to } 5.0 \text { ) when compared with nonusers }\end{array}$ & \\
\hline \multirow[t]{3}{*}{ Prospective cohort } & Increased risk & {$[28]$} \\
\hline & OCP use: relative risk $=1.5(95 \% \mathrm{Cl}=1.1$ to 2.1$)$ & \\
\hline & Postmenopausal hormones: relative risk $=1.9(95 \% \mathrm{Cl}=1.2$ to 3.1$)$ & \\
\hline
\end{tabular}

$\mathrm{Cl}$, confidence interval; OCP, oral contraceptive pill; SLE, systemic lupus erythematosus.

maternal or the paternal $\mathrm{X}$ chromosome. Women are thus functional mosaics for $\mathrm{X}$-linked genes, although several genes can escape this inactivation in physiologic conditions [54].

In some cases this activation can be skewed, with either the maternal or the paternal $X$ chromosome being more frequently active. This skewed $X$ chromosome inactivation has been implicated in Scl development [55]. In a recent study, the $\mathrm{X}$ chromosome inactivation patterns of female Scl patients and the parental origin of the inactive $X$ chromosome were investigated [56]. The authors found that skewed $X$ chromosome inactivation was observed in over $40 \%$ of patients compared with $8 \%$ of controls $(\mathrm{OR}=9.3,95 \% \mathrm{Cl}=$ 4.3 to 20.6). Extremely skewed $X$ chromosome inactivation was present in around $30 \%$ of patients compared with $2 \%$ of controls (OR $=16.9,95 \% \mathrm{Cl}=4.8$ to 70.4 ). It is unlikely that such skewing can by itself explain the increased susceptibility in women but this may be a co-factor in the pathogenetic trail.

\section{X chromosome monosomy}

$\mathrm{X}$ chromosome monosomy - where one $\mathrm{X}$ chromosome is absent - is another hypothesis that may explain the increased excess of $\mathrm{Scl}$ in females. The rate of monosomy $\mathrm{X}$, in peripheral white blood cells, was found to be significantly increased in a study of women with Scl or autoimmune thyroid disease when compared with healthy age-matched women $(6.2 \pm 0.3 \%$ and $4.3 \pm 0.3 \%$, respectively, vs. $2.9 \pm$ $0.2 \%$ in healthy women; $P<0.0001$ in both comparisons) [57]. This may suggest a common role in autoimmune diseases. A recent study in women with SLE, however, found no increase in $\mathrm{X}$ monosomy rates when compared with healthy women [58].

\section{Klinefelter's syndrome}

Klinefelter's syndrome $(47, \mathrm{XXY})$ - a genetic chromosomal abnormality associated with the presence of one additional $X$ chromosome in men due to abnormal division - has in isolated reports been reported to co-exist with SLE. A recent study has investigated this syndrome in a large population of patients with SLE [59]. The authors found that the frequency of Klinefelter's syndrome, which was often subclinical, was 14-fold higher in male SLE patients than in an unselected population. This increased susceptibility could be explained by an $\mathrm{X}$ chromosome gene-dose effect.

\section{Role of noninherited genetic factors}

Noninherited maternal antigens

Noninherited maternal antigens occur when there is a maternal-foetal genotype incompatibility, and they have been evaluated in relation to HLA DRB1 alleles. The hypothesis is that foetal exposure to maternal DRB1 susceptibility alleles carried by, but not inherited from, the mother increase the disease risk. There have been some reports of such alleles being associated with RA. A study of 100 families found there was an excess of $\mathrm{DRB} 1^{*} 04$ and shared epitope noninherited maternal antigens compared with noninherited paternal antigens, which may suggest a role for HLA noninherited maternal antigens in RA [60]. This was also 
observed in two independent populations [61]. Other studies, however, have suggested conflicting results [62]. A recent large family cohort study (North American Rheumatoid Arthritis Consortium) showed that there were differences when age at onset was studied [63]. The authors found that the risk of $\mathrm{RA}$ was associated with noninherited maternal antigens HLA-DR4 in women with an earlier age of onset ( $<45$ years) but not in men or women with an older age at onset, and they speculated that this may help explain previous conflicting results.

\section{Microchimerism}

A longer-term effect of pregnancy is the persistence of foetal cells in women after a pregnancy and of maternal cells in her offspring, known as microchimerism. These cells can be haematopoietic or can differentiate into somatic cells in multiple organs, and are found in both healthy individuals and those with autoimmune diseases. How these cells are tolerated by the immune system is poorly understood but it is possible that if these cells are targeted as foreign cells they could be implicated in the pathogenesis of autoimmune diseases. In a study of 40 women who had previously given birth to a son, male cell DNA equivalents were significantly raised in Scl patients $(0.38$ cells $/ 16 \mathrm{ml}$ in controls compared with 11.1 cells $/ 16 \mathrm{ml}$ in patients) [64]. HLA-class II compatibility of the child (from a mother's perspective) was also found to be more common in Scl patients, and supports the possibility of microchimerism being involved in the pathogenesis of Scl. Microchimerism in peripheral blood mononuclear cells has been shown to be more frequent in women with Scl than healthy controls [65]. A case study also implicated foetal cells in the development of SLE [66]. The results of such studies have not always been consistent, with a study of 22 SLE patients and 24 healthy controls finding no difference in the number of microchimeric cells between the patients and controls [67]. A recent study has also shown that microchimerism with male DNA is also found in women who have never given birth to a son, and suggests other sources of DNA, not only a history of a male birth, must be used in research studies [68].

A novel finding has been the transfer, through microchimerism, of the shared epitope - a strong risk factor associated with RA - in women with RA [69]. The authors found that, compared with healthy women, patients with RA had a higher frequency and higher levels of $\mathrm{DRB} 1{ }^{*} 04$ microchimerism ( $42 \%$ vs. $8 \%, P=0.00002)$ and $\mathrm{DRB} 1{ }^{\star} 01$ microchimerism (30\% vs. $4 \%, P=0.00002$ ). There was no difference for microchimerism in alleles that were not associated with RA. This study is the first to provide evidence that HLA susceptibility alleles can contribute to the risk of an autoimmune disease though microchimerism.

\section{Environmental differences}

One obvious line of enquiry to explain female excess incidence is that there are gender differences in exposure to environmental and lifestyle risk factors. There have, however, been relatively few environmental exposures that can contribute importantly to the female excess of autoimmune diseases.

\section{Work/occupation}

One of the major differences between the genders is in occupational exposures to potential toxins. For many occupations, however, males are traditionally exposed to more harmful products - so far more male cases would be expected from these risk factors alone. Although occupational exposure to silica is a known risk factor for autoimmune diseases, even in women [70], exposure to silica (for example, coal mining) is much more common in males.

\section{Other lifestyle factors}

There are some suggestions that chemicals to which women are exposed from the use of cosmetics and hair dyes could help to explain why women get more autoimmune disease. Lupus can be induced by ingestion of drugs containing aromatic amines or hydrazine. The use of hair dye products have been postulated as a possible risk factor for SLE as they contain aromatic amines, but a large cohort study (the Nurses' Health Study) found no increased risk [71].

An interesting association has been found with lipstick use and SLE [72]. Researchers found that using lipstick for 3 days/week was significantly associated with SLE and this may be worth considering in future studies on environmental risk factors. The authors suggest that chemicals present in lipsticks may be absorbed across the buccal mucosa and have a biological effect on disease development.

\section{Silicone implants}

Nearly 30 years ago there were several case reports indicating a connection between silicone implants and Scl [73]. This has been the subject of some debate as many reports have found no increased risk, including a large case-control study on the risk of SLE with silicone implants [74]. A recent review of a number of case-control studies, cohort studies and critical reviews summarized that there is no connection between connective tissue diseases, including RA, SLE and Scl, and silicone implants [75]. Even if there was a risk for women who have implants, given the prevalence of autoimmune diseases and the proportion of women with implants, it is unlikely that this risk factor is substantial enough to make a difference to disease incidence.

\section{Smoking}

Cigarette smoking is a risk factor for RA in both genders, although there do appear to be some interesting gender effects. Cohort studies of postmenopausal women have shown that smoking (both duration and intensity) is linked with an increased risk of RA [76]. A case-control study in Finland showed that there is a statistical interaction between smoking and gender [77]. Amongst women there are 
significant interactions between smoking and age. It may be that gender is a biological effect modifier in the association between smoking and RA. There is also a gene-environment interaction between smoking and the risk of RA, which has been observed in a cohort of women with both the shared epitope and a polymorphism in glutathione S-transferase M1 [78]. The disease phenotype for RA is different between genders, with males having a later disease onset, being more likely to show seropositivity for rheumatoid factor and having higher levels of anti-citrullinated peptide antibodies [79]. These results cannot just be attributed to differences in tobacco exposure or to the presence of the shared epitope of other HLA genetic variation.

\section{Conclusions}

How the role of genes, of hormones and of the environment and the increased susceptibility to autoimmune disease can be disentangled remains to be fully addressed. As highlighted in a recent review on sex and SLE, it is incorrect to combine all autoimmune diseases into a single mechanistic construct [80]. Timing of intervention either for disease induction, prevention or treatment will differ between diseases. A greater understanding of both genetic and epigenetic influences will emerge with the intensive research efforts in these areas permitted by new technologies. For example, high-density chromosome wide association studies are required to further determine the role of sex chromosomes in autoimmune diseases, and studies of larger numbers of men with autoimmune diseases would also provide further insights [81]. Similarly, gene arrays may guide the identification of oestrogen-responsive genes. The female predominance in the diseases considered could reflect differences in ascertainment, although this is a very unlikely explanation for the major part of the female excess observed. Furthermore the question may be turned on its head, and the issue of why men are protected against these diseases is more relevant [54,81]. Physician awareness of these diseases in women will perhaps lead to more questioning and testing for the disease; the opposite case has recently been illustrated with coronary heart disease - a male-predominant disease [82].

The hormonal story remains the most compelling, although it lacks a consistent specific path. Autoimmunity is a complex process in which both environmental and genetic factors influence disease susceptibility; in addition, there are possibly other, as yet unknown, factors that co-exist.

\section{Competing interests}

The authors declare that they have no competing interests.

\section{References}

1. Fairweather D, Frisancho-Kiss S, Rose NR: Sex differences in autoimmune disease from a pathological perspective. Am J Pathol 2008, 173:600-609.

2. Sokka T, Toloza S, Cutolo M, Kautiainen H, Makinen H, Gogus F, Skakic V, Badsha H, Peets T, Baranauskaite A, Geher P, Ujfalussy I, Skopouli FN, Mavrommati M, Alten R, Pohl C, Sibilia J, Stancati A, Salaffi F, Romanowski W, Zarowny-Wierzbinska D, Henrohn D,
Bresnihan B, Minnock P, Knudsen LS, Jacobs JW, Calvo-Alen J, Lazovskis J, Pinheiro GD, Karateev D, et al.: Women, men, and rheumatoid arthritis: analyses of disease activity, disease characteristics, and treatments in the QUEST-RA Study. Arthritis Res Ther 2009, 11:R7.

3. Wiles N, Symmons DP, Harrison B, Barrett E, Barrett JH, Scott DG, Silman AJ: Estimating the incidence of rheumatoid arthritis: trying to hit a moving target? Arthritis Rheum 1999, 42: 1339-1346.

4. Chifflot H, Fautrel B, Sordet C, Chatelus E, Sibilia J: Incidence and prevalence of systemic sclerosis: a systematic literature review. Semin Arthritis Rheum 2008, 37:223-235.

5. Steen VD, Oddis CV, Conte CG, Janoski J, Casterline GZ, Medsger TA, Jr: Incidence of systemic sclerosis in Allegheny County, Pennsylvania. A twenty-year study of hospital-diagnosed cases, 1963-1982. Arthritis Rheum 1997, 40:441-445.

6. D'Cruz DP, Khamashta MA, Hughes GR: Systemic lupus erythematosus. Lancet 2007, 369:587-596.

7. Alamanos Y, Voulgari PV, Drosos AA: Incidence and prevalence of rheumatoid arthritis, based on the 1987 American College of Rheumatology criteria: a systematic review. Semin Arthritis Rheum 2006, 36:182-188.

8. Silman AJ: Rheumatoid arthritis. In Epidemiology of the rheumatic diseases. 2nd edition. Edited by Silman AJ, Hochberg MC. Oxford: Oxford University Press; 2001:31-71.

9. Petri M: Epidemiology of systemic lupus erythematosus. Best Pract Res Clin Rheumatol 2002, 16:847-858.

10. Rus V, Hajeer A, Hochberg MC: Systemic lupus erythematosus. In Epidemiology of the rheumatic diseases. 2nd edition. Edited by Silman AJ, Hochberg MC. Oxford: Oxford University Press; 2001:123-140.

11. Silman AJ: Scleroderma. In Epidemiology of the rheumatic diseases. 2nd edition. Edited by Silman AJ, Hochberg MC. Oxford: Oxford University Press; 2001:141-162.

12. Laing TJ, Gillespie BW, Toth MB, Mayes MD, Gallavan RH, Jr, Burns CJ, Johanns JR, Cooper BC, Keroack BJ, Wasko MC, Lacey JV, Jr, Schottenfeld D: Racial differences in scleroderma among women in Michigan. Arthritis Rheum 1997, 40:734-742.

13. Zandman-Goddard G, Peeva E, Shoenfeld Y: Gender and autoimmunity. Autoimmun Rev 2007, 6:366-372.

14. Cutolo M, Seriolo B, Villaggio B, Pizzorni C, Craviotto C, Sulli A: Androgens and estrogens modulate the immune and inflammatory responses in rheumatoid arthritis. Ann N Y Acad Sci 2002, 966:131-142.

15. Lang TJ: Estrogen as an immunomodulator. Clin Immunol 2004, 113:224-230.

16. Nilsson BO: Modulation of the inflammatory response by estrogens with focus on the endothelium and its interactions with leukocytes. Inflamm Res 2007, 56:269-273.

17. Rider V, Foster RT, Evans M, Suenaga R, Abdou NI: Gender differences in autoimmune diseases: estrogen increases calcineurin expression in systemic lupus erythematosus. Clin Immunol Immunopathol 1998, 89:171-180.

18. Rider V, Jones SR, Evans M, Abdou NI: Molecular mechanisms involved in the estrogen-dependent regulation of calcineurin in systemic lupus erythematosus T cells. Clin Immunol 2000, 95:124-134.

19. Rider V, Abdou NI: Gender differences in autoimmunity: molecular basis for estrogen effects in systemic lupus erythematosus. Int Immunopharmacol 2001, 1:1009-1024.

20. Orbach $\mathrm{H}$, Shoenfeld $\mathrm{Y}$ : Hyperprolactinemia and autoimmune diseases. Autoimmun Rev 2007, 6:537-542.

21. Spector TD, Perry LA, Tubb G, Silman AJ, Huskisson EC: Low free testosterone levels in rheumatoid arthritis. Ann Rheum Dis 1988, 47:65-68.

22. Heikkila $R$, Aho K, Heliovaara M, Knekt $P$, Reunanen A, Aromaa A, Leino A, Palosuo T: Serum androgen-anabolic hormones and the risk of rheumatoid arthritis. Ann Rheum Dis 1998, 57:281285.

23. Spector TD, Ollier W, Perry LA, Silman AJ, Thompson PW, Edwards A: Free and serum testosterone levels in 276 males: a comparative study of rheumatoid arthritis, ankylosing spondylitis and healthy controls. Clin Rheumatol 1989, 8:37-41.

24. Masi AT: Hormonal and immunologic risk factors for the development of rheumatoid arthritis: an integrative physiopathogenetic perspective. Rheum Dis Clin North Am 2000, 26:775-803. 
25. Masi AT, Aldag JC: Integrated neuroendocrine immune risk factors in relation to rheumatoid arthritis: should rheumatologists now adopt a model of a multiyear, presymptomatic phase? Scand J Rheumatol 2005, 34:342-352.

26. Tengstrand B, Carlstrom K, Fellander-Tsai L, Hafstrom I: Abnormal levels of serum dehydroepiandrosterone, estrone, and estradiol in men with rheumatoid arthritis: high correlation between serum estradiol and current degree of inflammation. J Rheumatol 2003, 30:2338-2343.

27. McMurray RW, May W: Sex hormones and systemic lupus erythematosus: review and meta-analysis. Arthritis Rheum 2003, 48:2100-2110.

28. Costenbader KH, Feskanich D, Stampfer MJ, Karlson EW: Reproductive and menopausal factors and risk of systemic lupus erythematosus in women. Arthritis Rheum 2007, 56:1251-1262.

29. Karlson EW, Mandl LA, Hankinson SE, Grodstein F: Do breastfeeding and other reproductive factors influence future risk of rheumatoid arthritis? Results from the Nurses' Health Study. Arthritis Rheum 2004, 50:3458-3467.

30. de Man YA, Dolhain RJ, van de Geijn FE, Willemsen SP, Hazes JM: Disease activity of rheumatoid arthritis during pregnancy: results from a nationwide prospective study. Arthritis Rheum 2008, 59:1241-1248

31. Nelson JL, Ostensen M: Pregnancy and rheumatoid arthritis. Rheum Dis Clin North Am 1997, 23:195-212.

32. Silman A, Kay A, Brennan P: Timing of pregnancy in relation to the onset of rheumatoid arthritis. Arthritis Rheum 1992, 35: 152-155.

33. Lambe M, Bjornadal L, Neregard P, Nyren O, Cooper GS: Childbearing and the risk of scleroderma: a population-based study in Sweden. Am J Epidemiol 2004, 159:162-166.

34. Brennan $P$, Silman $A$ : Breast-feeding and the onset of rheumatoid arthritis. Arthritis Rheum 1994, 37:808-813.

35. Brennan P, Ollier B, Worthington J, Hajeer A, Silman A: Are both genetic and reproductive associations with rheumatoid arthritis linked to prolactin? Lancet 1996, 348:106-109.

36. Russell AS, Johnston C, Chew C, Maksymowych WP: Evidence for reduced Th1 function in normal pregnancy: a hypothesis for the remission of rheumatoid arthritis. J Rheumatol 1997, 24:1045-1050.

37. Barrett $\mathrm{JH}$, Brennan $\mathrm{P}$, Fiddler M, Silman AJ: Does rheumatoid arthritis remit during pregnancy and relapse postpartum? Results from a nationwide study in the United Kingdom performed prospectively from late pregnancy. Arthritis Rheum 1999, 42:1219-1227

38. Barrett JH, Brennan $\mathrm{P}$, Fiddler M, Silman A: Breast-feeding and postpartum relapse in women with rheumatoid and inflammatory arthritis. Arthritis Rheum 2000, 43:1010-1015.

39. Chuang E, Molitch ME: Prolactin and autoimmune diseases in humans. Acta Biomed 2007, 78(Suppl 1):255-261.

40. Pikwer M, Bergstrom U, Nilsson JA, Jacobsson L, Berglund G, Turesson C: Breast-feeding, but not oral contraceptives, is associated with a reduced risk of rheumatoid arthritis. Ann Rheum Dis 2009, 68:526-530.

41. Cooper GS, Dooley MA, Treadwell EL, St Clair EW, Gilkeson GS: Hormonal and reproductive risk factors for development of systemic lupus erythematosus - results of a populationbased, case-control study. Arthritis Rheum 2002, 46:18301839.

42. Pisa FE, Bovenzi M, Romeo L, Tonello A, Biasi D, Bambara LM, Betta A, Barbone F: Reproductive factors and the risk of scleroderma: an Italian case-control study. Arthritis Rheum 2002, 46:451-456.

43. Artlett CM, Rasheed M, Russo-Stieglitz KE, Sawaya HH, Jimenez $\mathrm{SA}$ : Influence of prior pregnancies on disease course and cause of death in systemic sclerosis. Ann Rheum Dis 2002, 61:346-350.

44. Hannaford PC, Kay CR, Hirsch S: Oral contraceptives and rheumatoid arthritis: new data from the Royal College of General Practitioners' oral contraception study. Ann Rheum Dis 1990, 49:744-746.

45. Oliver JE, Silman AJ: Risk factors for the development of rheumatoid arthritis. Scand J Rheumatol 2006, 35:169-174.

46. Doran MF, Crowson CS, O'Fallon WM, Gabriel SE: The effect of oral contraceptives and estrogen replacement therapy on the risk of rheumatoid arthritis: a population based study. J Rheumato/ 2004, 31:207-213.
47. Walitt B, Pettinger M, Weinstein A, Katz J, Torner J, Wasko MC, Howard BV: Effects of postmenopausal hormone therapy on rheumatoid arthritis: the women's health initiative randomized controlled trials. Arthritis Rheum 2008, 59:302-310.

48. Garcia Rodriguez LA, Tolosa LB, Ruigomez A, Johansson S, Wallander MA: Rheumatoid arthritis in UK primary care: incidence and prior morbidity. Scand J Rheumatol 2009, 38:173-177.

49. Santos-Ocampo AS: New onset systemic lupus erythematosus in a transgender man: possible role of feminizing sex hormones. J Clin Rheumatol 2007, 13:29-30.

50. Yurino $\mathrm{H}$, Ishikawa $\mathrm{S}$, Sato $\mathrm{T}$, Akadegawa $\mathrm{K}$, Ito $T$, Ueha $S$ Inadera $\mathrm{H}$, Matsushima K: Endocrine disruptors (environmental estrogens) enhance autoantibody production by B1 cells. Toxicol Sci 2004, 81:139-147.

51. Petri M, Kim MY, Kalunian KC, Grossman J, Hahn BH, Sammaritano LR, Lockshin M, Merrill JT, Belmont HM, Askanase AD, McCune WJ, Hearth-Holmes M, Dooley MA, Von FJ, Friedman A, Tan M, Davis J, Cronin M, Diamond B, Mackay M, Sigler L, Fillius $M$, Rupel A, Licciardi F, Buyon JP: Combined oral contraceptives in women with systemic lupus erythematosus. $N$ Engl J Med 2005, 353:2550-2558.

52. Sanchez-Guerrero J, Uribe AG, Jimenez-Santana L, MestanzaPeralta M, Lara-Reyes P, Seuc AH, Cravioto MD: A trial of contraceptive methods in women with systemic lupus erythematosus. N Engl J Med 2005, 353:2539-2549.

53. Wellcome Trust Case Control Consortium: Genome-wide association study of 14,000 cases of seven common diseases and 3,000 shared controls. Nature 2007, 447:661-678.

54. Lleo A, Battezzati PM, Selmi C, Gershwin ME, Podda M: Is autoimmunity a matter of sex? Autoimmun Rev 2008, 7:626630.

55. Ozbalkan Z, Bagislar S, Kiraz S, Akyerli CB, Ozer HT, Yavuz S, Birlik AM, Calguneri M, Ozcelik T: Skewed $X$ chromosome inactivation in blood cells of women with scleroderma. Arthritis Rheum 2005, 52:1564-1570.

56. Uz E, Loubiere LS, Gadi VK, Ozbalkan Z, Stewart J, Nelson JL, Ozcelik T: Skewed X-chromosome inactivation in scleroderma. Clin Rev Allergy Immunol 2008, 34:352-355

57. Invernizzi $P$, Miozzo M, Selmi $C$, Persani $L$, Battezzati $P M$, Zuin $M$ Lucchi S, Meroni PL, Marasini B, Zeni S, Watnik M, Grati FR, Simoni G, Gershwin ME, Podda M: X chromosome monosomy: a common mechanism for autoimmune diseases. J Immunol 2005, 175:575-578

58. Invernizzi $\mathrm{P}$, Miozzo M, Oertelt-Prigione S, Meroni PL, Persani L, Selmi C, Battezzati PM, Zuin M, Lucchi S, Marasini B, Zeni S, Watnik M, Tabano S, Maitz S, Pasini S, Gershwin ME, Podda M: $\mathrm{X}$ monosomy in female systemic lupus erythematosus. Ann NY Acad Sci 2007, 1110:84-91.

59. Scofield RH, Bruner GR, Namjou B, Kimberly RP, RamseyGoldman R, Petri M, Reveille JD, Alarcon GS, Vila LM, Reid J, Harris B, Li S, Kelly JA, Harley JB: Klinefelter's syndrome $(47, X X Y)$ in male systemic lupus erythematosus patients: support for the notion of a gene-dose effect from the $X$ chromosome. Arthritis Rheum 2008, 58:2511-2517.

60. Harney S, Newton J, Milicic A, Brown MA, Wordsworth BP: Noninherited maternal HLA alleles are associated with rheumatoid arthritis. Rheumatology (Oxford) 2003, 42:171-174.

61. van der Horst-Bruinsma IE, Hazes JM, Schreuder GM, Radstake TR, Barrera $P$, van de Putte LB, Mustamu D, van SD, Breedveld FC, de Vries RR: Influence of non-inherited maternal HLA-DR antigens on susceptibility to rheumatoid arthritis. Ann Rheum Dis 1998, 57:672-675.

62. Barrera P, Balsa A, Alves H, Westhovens R, Maenaut K, Cornelis F, Fritz P, Bardin T, de Almeida G, Lopes-Vaz A, Pascual SD, de la Concha EG, Radstake TR, van de Putte LB, Migliorini P, Prud'homme JF, Charron D, Spyropoulou M, Mendes A, Spaepen M, Martinez M, Lepage V, Stravopoulos C: Noninherited maternal antigens do not play a role in rheumatoid arthritis susceptibility in Europe. European Consortium on Rheumatoid Arthritis Families. Arthritis Rheum 2000, 43:758-764.

63. Guthrie KA, Tishkevich NR, Nelson JL: Non-inherited maternal human leukocyte antigen alleles in susceptibility to familial rheumatoid arthritis. Ann Rheum Dis 2009, 68:107-109.

64. Nelson JL, Furst DE, Maloney S, Gooley T, Evans PC, Smith A, Bean MA, Ober C, Bianchi DW: Microchimerism and HLA-compatible relationships of pregnancy in scleroderma. Lancet 1998, 351:559-562. 
65. Evans PC, Lambert N, Maloney S, Furst DE, Moore JM, Nelson JL: Long-term fetal microchimerism in peripheral blood mononuclear cell subsets in healthy women and women with scleroderma. Blood 1999, 93:2033-2037.

66. Johnson $\mathrm{KL}$, McAlindon TE, Mulcahy $\mathrm{E}$, Bianchi DW: Microchimerism in a female patient with systemic lupus erythematosus. Arthritis Rheum 2001, 44:2107-2111.

67. Mosca M, Curcio M, Lapi S, Valentini G, D'Angelo S, Rizzo G, Bombardieri S: Correlations of $Y$ chromosome microchimerism with disease activity in patients with SLE: analysis of preliminary data. Ann Rheum Dis 2003, 62:651-654.

68. Lambert NC, Pang JM, Yan Z, Erickson TD, Stevens AM, Furst $\mathrm{DE}$, Nelson JL: Male microchimerism in women with systemic sclerosis and healthy women who have never given birth to a son. Ann Rheum Dis 2005, 64:845-848.

69. Rak JM, Maestroni L, Balandraud N, Guis S, Boudinet H, Guzian MC, Yan Z, Azzouz D, Auger I, Roudier C, Martin M, Didelot R, Roudier J, Lambert NC: Transfer of the shared epitope through microchimerism in women with rheumatoid arthritis. Arthritis Rheum 2008, 60:73-80.

70. Finckh A, Cooper GS, Chibnik LB, Costenbader KH, Watts J, Pankey $\mathrm{H}$, Fraser PA, Karlson EW: Occupational silica and solvent exposures and risk of systemic lupus erythematosus in urban women. Arthritis Rheum 2006, 54:3648-3654.

71. Sanchez-Guerrero J, Karlson EW, Colditz GA, Hunter DJ, Speizer $\mathrm{FE}$, Liang $\mathrm{MH}$ : Hair dye use and the risk of developing systemic lupus erythematosus. Arthritis Rheum 1996, 39:657-662.

72. Wang J, Kay AB, Fletcher J, Formica MK, McAlindon TE: Is lipstick associated with the development of systemic lupus erythematosus (SLE)? Clin Rheumato/ 2008, 27:1183-1187.

73. Spiera H, Kerr LD: Scleroderma following silicone implantation: a cumulative experience of 11 cases. J Rheumatol 1993, 20:958-961.

74. Strom BL, Reidenberg MM, Freundlich B, Schinnar R: Breast silicone implants and risk of systemic lupus erythematosus. J Clin Epidemiol 1994, 47:1211-1214.

75. Lipworth L, Tarone RE, McLaughlin JK: Silicone breast implants and connective tissue disease: an updated review of the epidemiologic evidence. Ann Plast Surg 2004, 52:598-601.

76. Criswell LA, Merlino LA, Cerhan JR, Mikuls TR, Mudano AS, Burma M, Folsom AR, Saag KG: Cigarette smoking and the risk of rheumatoid arthritis among postmenopausal women: results from the lowa Women's Health Study. Am J Med 2002, 112:465-471.

77. Krishnan E, Sokka T, Hannonen P: Smoking-gender interaction and risk for rheumatoid arthritis. Arthritis Res Ther 2003, 5: R158-R162.

78. Criswell LA, Saag KG, Mikuls TR, Cerhan JR, Merlino LA, Lum RF, Pfeiffer KA, Woehl B, Seldin MF: Smoking interacts with genetic risk factors in the development of rheumatoid arthritis among older Caucasian women. Ann Rheum Dis 2006, 65: 1163-1167.

79. Jawaheer D, Lum RF, Gregersen PK, Criswell LA: Influence of male sex on disease phenotype in familial rheumatoid arthritis. Arthritis Rheum 2006, 54:3087-3094.

80. Lockshin MD: Biology of the sex and age distribution of systemic lupus erythematosus. Arthritis Rheum 2007, 57:608-611.

81. Selmi C: The $X$ in sex: how autoimmune diseases revolve around sex chromosomes. Best Pract Res Clin Rheumatol 2008, 22:913-922.

82. Arber S, McKinlay J, Adams A, Marceau L, Link C, O'Donnell A: Patient characteristics and inequalities in doctors' diagnostic and management strategies relating to CHD: a video-simulation experiment. Soc Sci Med 2006, 62:103-115.

83. Alamanos $Y$, Drosos AA: Epidemiology of adult rheumatoid arthritis. Autoimmun Rev 2005, 4:130-136.

84. Sanchez-Guerrero J, Karlson EW, Liang MH, Hunter DJ, Speizer FE, Colditz GA: Past use of oral contraceptives and the risk of developing systemic lupus erythematosus. Arthritis Rheum 1997, 40:804-808.

85. Meier CR, Sturkenboom MCJM, Cohen AS, Jick H: Postmenopausal estrogen replacement therapy and the risk of developing systemic lupus erythematosus or discoid lupus. $J$ Rheumatol 1998, 25:1515-1519. 